J. Amer. Soc. Hort. Sci. 127(5):729-736. 2002.

\title{
Pollen Mobilization in Selected Cucurbitaceae and the Putative Effects of Pollinator Abundance on Pollen Depletion Rates
}

\author{
M.S. Stanghellini \\ Department of Entomology, Box 7626, North Carolina State University, Raleigh, NC 27695-7626 \\ J.R. Schultheis \\ Department of Horticultural Science, Box 7609, North Carolina State University, Raleigh, NC 27695-7609
}

J.T. Ambrose

Department of Entomology, Box 7626, North Carolina State University, Raleigh, NC 27695-7626

\begin{abstract}
ADDiTIONAL INDEX WORDS. cucumber, Cucumis sativus, muskmelon, Cucumis melo, watermelon, Citrullus lanatus, pollen depletion

Aвstract. Very little is known about the rate at which pollen grains are mobilized within insect-pollinated crop systems, and this is especially true the for commercial production of field-grown cucumber (Cucumis sativus L.), monoecious muskmelon (Cucumis melo L.), and triploid watermelon [Citrullus lanatus (Thunb.) Matsum. \& Nakai]. The rates of pollen depletion for these crops were therefore investigated on plots simulating commercial crop production using a mixed honey bee (Apis mellifera L.) and bumble bee (Bombus impatiens Cresson) pollinator complex. At anthesis, staminate cucumber, muskmelon, and watermelon flowers contained on average 10539, 11176, and 30739 pollen grains/flower, respectively. At the time flowers closed in the early afternoon (1300 to $1400 \mathrm{HR})$, only $61 \%$ of the total pollen produced had been removed from staminate cucumber flowers, $44 \%$ to $62 \%$ from muskmelon, and $81 \%$ from watermelon flowers. The results suggest that total pollen production in these crops may not necessarily reflect total pollen availability to floral visitors (bees). However, of the total amount of pollen actually removed per flower, $>57 \%$ occurred during the $2 \mathrm{~h}$ following flower anthesis of cucumber and muskmelon, and $>77 \%$ occurred during the $2 \mathrm{~h}$ following flower anthesis of watermelon. Thus, most of the accessible pollen was removed shortly after anthesis, which is when these crops are most receptive to pollination. Nonviable triploid and viable diploid watermelon pollen were removed at similar rates $(P=\mathbf{0 . 4 6 0 4})$. While correlation analyses were not possible for the influence of variable bee abundance on pollen depletion rates, higher bee populations in one year appeared to increase the rate at which pollen grains were removed from staminate flowers.
\end{abstract}

The successful removal of pollen from angiosperm flowers is an integral component of both plant mating systems and the behavioral dynamics of flower-visiting animals (Kearns and Inouye, 1993). In terms of plant mating, pollen mobilization is a key factor of various evolutionary phenomena such as outcrossing potential and paternal fitness, pollen-mediated gene flow, and seed production and vigor. These, in turn, have direct bearing on plant population dynamics and community structure (e.g., Knapp et al., 1991; Kohn and Casper, 1992; Levin, 1981; Spira et al., 1992; Waser and Price, 1983, 1991; Williams et al., 1997). Likewise, the pollen harvesting ability of various floral visitors may be an indicator of their efficiency at collecting food resources (Kearns and Inouye, 1993; Strickler, 1979); which would, in turn, affect the animal's health and vigor, reproduction rate and overall reproductive success of the individual animal (if solitary) or colony of animals (e.g., social insects like honey bees, Apis mellifera L.).

Within the confines of crop pollination, the successful mobilization of pollen is a primary factor affecting yield of many plant products (fruits and seeds). This is particularly true for species that require or benefit from cross-pollination. For example, crops and/or

Received for publication 6 Nov. 2001. Accepted for publication 25 Apr. 2002. This research was funded in part by the North Carolina Agricultural Research Service (NCARS Project 6355); Koppert Biological Systems, Inc., Ann Arbor, Mich.; the North Carolina Department of Agriculture and Consumer Affairs; and the North Carolina State Beekeepers Association. Use of trade names in this publication does not imply endorsement by the NCARS of products named nor criticism of similar ones not mentioned. We gratefully acknowledge Cavell Brownie for providing statistical advise, and Christopher Mahan, Mark Gallo, Jennifer Keller, Zach Myers, Jake Yahnker, and all station personnel at the Central Crops research Station, Clayton, North Carolina, for providing technical assistance. cultivars that are largely self-infertile require the interplanting of viable pollen sources (pollinizers) for successful fruit and seed set, as found in almond [Prunus dulcis (Miller) D.A. Webb], apple (Malus domestica Borkh), pear (Pyrus communis L.), plum (Prunus sp.), and sweet cherry (Prunus avium $\mathrm{L}$.) orchards. The relationship between reduced fruit set on self-infertile trees at increasing distances from pollinizer trees is well documented (Free, 1993).

Aside from the dependence of fruit tissue growth on hormonal responses initiated by pollen tube growth and ovule fertilization, pollen removal and deposition between conspecific flowers by floral visitors also influences the relative efficiency of commercial hybrid seed production (e.g., insect-mediated vs. manual pollination). For instance, problems with or lack of consistent insectmediated pollen transfer from viable pollen-bearing plants to malesterile plants has been viewed as a major limiting factor in the commercial production of hybrid onion (Allium cepa $\mathrm{L}$.) and upland cotton (Gossypium hirsutum L.) seed (Berger et al., 1988; Bohart et al., 1970; Gary et al., 1972; Niles and Feaster, 1984).

Research investigating total pollen production and the subsequent rate(s) of depletion from pollen-bearing flowers are relatively uncommon for both natural and commercial crop plant systems. For cucurbits, only four studies describe pollen mobilization research. Through visual estimation of pollen levels remaining in anthers, Orr and Eisikowitch (1988) reported seasonal differences in pollen withdrawal rates by sampling staminate and hermaphrodite flowers of muskmelon (Cucumis melo L.) during spring (cooler conditions; slower rate) vs. autumn (warmer conditions; faster rate) plantings in Israel. Mann (1953) also investigated pollen removal rates using an andromonoecious line of muskmelon. He found that the numbers of 
pollen grains per flower present at anthesis and remaining 4 and 8 $\mathrm{h}$ after anthesis were 8000 to 13000,3000 to 4000, and 2000, respectively. While evaluating the genetic variability of selected diploid watermelon lines [Citrullus lanatus (Thunb.) Matsum. \& Nakai] for relative attractiveness to honey bees, Wolf et al. (1999) found that cultivars producing a greater quantity and quality of nectar were more attractive to honey bees and that pollen removal was more rapid on these more attractive plants. Girish (1981; cited in Free, 1993) reported that staminate summer squash (Cucurbita pepo L.) flowers contained 10000 to 11000 pollen grains at anthesis, but that only 500 remained by the time flowers closed several hours later.

Cucumber production has undergone considerable modifications in the last 35 years with the development of predominantly gynoecious cultivars and the switch to high-density field populations which range from 160,00 to 250,000 plants/ha (Motes, 1977; Vann Wann, 1993). Monoecious plants are intermixed (10\% to $12 \%$ seed blend) with the gynoecious plants to provide pollen for fruit and seed set (Connor and Martin, 1971). Thus, there is a relatively low proportion of pollen-bearing plants in relation to that of the gynoecious plants (1 monoecious : 10 gynoecious). To achieve maximum, onceover, mechanical harvest of pickling cucumbers, one to several flowers per vine must be pollinated within 4 to $7 \mathrm{~d}$ of each other (Connor and Martin, 1970). To accomplish optimal pollination under this production regime requires that an efficient pollinator force be active during this brief fruit setting period.

Although previous studies on pollen depletion for andromonoecious muskmelons exist, there are no data for monoecious plant forms which have recently gained production favor in some parts of the United States, particularly in the Southeast (Sanders et al., 1999). Pollen production and depletion rates in triploid watermelon systems are also of considerable interest as pollen from triploid plants is nonviable, thereby requiring the interplanting of diploid plants to serve as pollinizers. Currently, $25 \%$ to $33 \%$ of triploid field space is devoted to pollinizer plants and insect vectors (bees) are needed to mobilize and transfer viable pollen from staminate diploid flowers onto pistillate flowers of nearby triploid plants. Very little or nothing is known about the production, rate of removal, or fate of triploid pollen in seedless watermelon production fields.

For the past seven years, we have been evaluating the potential of commercial bumble bee (Bombus impatiens Cresson) colonies as alternative pollinators for honey bees on selected vine crops (Stanghellini et al., 1997, 1998a, 1998b, 2002). As an adjunct to this research, we were afforded the opportunity to investigate pollen mobilization on these crops. Here we present quantitative pollen mobilization data for the following: 1) plots simulating commercial production of predominantly gynoecious pickling and fresh-market cucumbers with a $10 \%$ to $12 \%$ monoecious seed blend; 2) plots simulating commercial muskmelon production using a monoecious cultivar; and 3) plots simulating both a solid diploid (seeded) watermelon field and a standard triploid (seedless) watermelon production field which devoted $33 \%$ of field space to diploid pollinizers. Possible effects of pollinator type and abundance on differential pollen depletion rates between years are also discussed.

\section{Materials and Methods}

Cultural practices. The experimental plots used in these studies were designed to compare the pollination efficacy of honey bees and bumble bees on selected cucurbit crops. Accordingly, two commercial colonies of each species were placed within $10 \mathrm{~m}$ of the field border 5 to $7 \mathrm{~d}$ after the appearance of the first flowers on the test plants. Honey bee colonies $(\approx 30,000$ adult bees/colony) were from the North Carolina State University apiary. Bumble bee colonies ( $\approx 75$ to 150 adult bees/colony) were obtained from Koppert Biological Systems, Inc., Ann Arbor, Mich. The cardboard bumble bee nest boxes were placed in protective wooden stands $1 \mathrm{~m}$ in height next to the field.

Studies in both years were conducted at the Central Crops Research Station in North Carolina. Soil types differed between years as our cucurbit fields are in annual rotation with corn (Zea mays L.). Soil type in 1998 was Gilead Loamy Sand (Fine, kaolinitic, thermic Aquic Hapludult). Soil type in 1999 was Appling Sandy Loam (Fine, kaolinitic, thermic Typic Kanhapludult). Developing fruit were removed from vines every 3 to $4 \mathrm{~d}$ for cucumber and every 5 to $7 \mathrm{~d}$ for muskmelon and watermelon to induce continuous peak-bloom flowering levels. Plant irrigation, fertilization, and pest control measures followed that of standard commercial practices for North Carolina (Schultheis, 1995, 1998; Schultheis et al., 1998).

Cucumber. The experimental plots were designed to simulate commercial field production using predominantly gynoecious pickling and slicing cucumber cultivars. Plots in both years measured 46 $\times 6 \mathrm{~m}$ and consisted of four rows of plants (interrow spacing $1.2 \mathrm{~m}$ ). Two rows each of 'Calypso' (pickling cucumber) and 'Dasher II' (fresh-market cucumber), both with a $10 \%$ to $12 \%$ seed blend of 'Sumter' (pollinizer), were direct seeded on 15 May 1998 and 19 May 1999. Once germinated, plants were thinned to a between-plant spacing of $10 \mathrm{~cm}$, giving a final field population estimated at 900 plants of each gynoecious cultivar (450 plants/row), minus the $10 \%$ to $12 \%$ 'Sumter' plants ( $\approx 50$ plants/row).

MusKmelon. Although most muskmelon cultivars grown in the US are andromonoecious (Free, 1993), the monoecious cultivar, 'Athena', was chosen for this study as it is a predominant cultivar grown in the southeastern US (Sanders et al., 1999). Plots measured $46 \times 5 \mathrm{~m}$ and consisted of two rows of plants with an interrow spacing of $2.3 \mathrm{~m}$. Four to five seeds per hill were direct seeded on 15 May 1998 and 19 May 1999 with a between-plant spacing of $0.6 \mathrm{~m}$. Once germinated, hills were thinned to one plant/hill, giving final field populations of 150 muskmelon plants (75 plants/row) in each year.

Watermelon. Two watermelon cultivars, 'Fiesta' (diploid; seeded) and 'Tri-X 313' (triploid; seedless), were chosen as they are recommended cultivars for North Carolina (Sanders et al., 1999). In both years, containerized transplants were grown in a greenhouse for 21 to $25 \mathrm{~d}$, hardened outdoors for 5 to $7 \mathrm{~d}$, and then field-planted on 27 May 1998 and 6 June 1999. Watermelon plots measured 46 $\times 30 \mathrm{~m}$ and consisted of three, three-row sections divided by $4.6 \mathrm{~m}$ spray alleys used for pesticide and fungicide application. Each of the three sections contained two rows of 'Tri-X 313' and one row of 'Fiesta', with an interrow spacing of $2.3 \mathrm{~m}$. This arrangement allowed us to adequately simulate both the current standard planting scheme for commercial triploid watermelon production (every third row devoted to diploid plants; pollinizer density 33\%), and a solid diploid watermelon field, as flower and pollen production for 'Fiesta' and 'Tri-X313' are very similar (Stanghellini, 2000). For all rows, between-plant spacing was $1.0 \mathrm{~m}$, giving total field populations of 276 'Tri-X 313' and 138 'Fiesta' plants in each year.

FlOWER PRODUCTION, ANTHESIS PERIODS, AND BEE ABUNDANCE. Estimates of flower production were conducted when $>90 \%$ of the plants had produced one or more pistillate flowers. For each crop, flowers were quantified for 10 plants on four separate days (replicates) in both years. The total number of each flower type was then averaged to derive the mean number of staminate and pistillate flowers produced per plant per day. Although gynoecious cucumbers produce staminate flowers on occasion, all staminate flowers in 
cucumber plots were treated as if produced by 'Sumter' plants for convenience; regardless of source plant, staminate flowers produce viable pollen. Likewise, all pistillate cucumber flowers were treated as if they were produced by either 'Calypso' or 'Dasher II'; regardless of source plant, pistillate flowers are capable of developing into fruit.

For each crop, the times and air temperatures at which flowers opened and closed and when bumble bees and honey bees first initiated foraging activity were recorded. Temperatures were recorded using a HOBO (H8) temperature data logger (Onset Computer Corp., Bourne, Mass.) positioned $1 \mathrm{~m}$ off the ground in a shaded pine tree stand $15 \mathrm{~m}$ from the test field border. Bee abundance (number of foragers of each species) was also recorded during 3-min observation periods by walking random transects through plots. The primary objective for collecting bee foraging data was to determine the overall bee populations in the plots and to see how pollinator density might affect pollen mobilization rates. Detailed protocols for gathering bee abundance data and observed differences in foraging behavior between bee species were not the focus of this study and are described elsewhere (Stanghellini, 2000; Stanghellini et al., 2002).

Pollen Collection AND Processing. All samples were collected during the peak flowering and fruit setting phase of the crops. To determine total pollen production, staminate flowers were collected 10 to $30 \mathrm{~min}$ before anthesis and placed in screened containers to prevent pollen loss from insect visitation until natural corolla expansion and anther dehiscence were confirmed visually with a $10 \times$ hand lens. Staminate flowers were also collected at hourly intervals from anthesis to flower closure (0700 to $1400 \mathrm{HR}$ ). A total of 20 randomly chosen flowers for each hour were collected per cultivar in each year; five flowers per hour on four separate days per year (i.e., for each time period on each crop or cultivar in each year, $n=20)$.

After each flower was collected, the corolla was removed using a razor blade and the flower base with anthers was carefully pinched into individual $6 \mathrm{~mL}$ snap-cap style polyethylene vials containing 3 $\mathrm{mL}$ of a 1:1:2 formalin : $95 \%$ ethanol : $0.9 \%$ saline solution to preserve the pollen grains. Vials were vigorously shaken for $2 \mathrm{~min}$ to dislodge pollen grains remaining on and within the anthers. The flower base was then removed from the original vial, placed into a second vial containing $2 \mathrm{~mL}$ of the same preservation solution and shaken again to dislodge any pollen grains adhering to the plant tissues. This wash was then added back to the original vial. To confirm pollen removal, random samples of removed flower bases and anthers were inspected under a dissecting scope for remaining pollen grains. Very few (0 to 50) pollen grains were found on the surfaces of removed floral tissues or remaining inside dehisced anther sacs; thus, the shake-and-wash method was considered appropriate for these studies.

Pollen Quantification. The numbers of pollen grains per flower were quantified using an Elzone 180 particle counter fitted with a $190-\mu \mathrm{m}$-diameter aperture. Instrument calibration and operating procedures followed those described in the instruction manual (Particle Data, 1987). Detection threshold windows of $\pm 10 \mu \mathrm{m}$ were used for cucumber, muskmelon and watermelon pollen after obtaining average pollen grain diameter for each crop using a stage micrometer. Both cucumber and muskmelon pollen grains averaged $37 \mu \mathrm{m}$ in diameter, while both the diploid and triploid watermelon pollen grains averaged $68 \mathrm{~mm}$. Stored pollen samples were filtered through a $100 \mu \mathrm{m}$ polyethylene, macroporous filter (Spectrum Laboratories, Inc., Laguna Hills, Calif.) to remove any extraneous plant material. Individual samples were then diluted with saline $(0.9 \% \mathrm{NaCl})$ to a final volume of $20 \mathrm{~mL}$. Estimates of pollen levels were obtained by taking twelve $500 \mu \mathrm{L}$ subsamples from each whole-flower sample. Subsample values were then averaged and multiplied by 40 (total dilution factor) to derive the estimated total number of pollen grains per whole-flower sample. The five wholeflower samples per replication were then averaged to obtain replicate means used during analysis.

The accuracy and precision of particle counter readings were manually confirmed for random samples using a hemacytometer. Extrapolated totals for pollen grains/flower measurements derived with the hemacytometer were very similar to the estimate readings produced by the particle counter $( \pm 5 \%)$. Occasionally, aberrant readings were given by the counter; these were caused by aperture blockage from oversized or oddly shaped particles (e.g., trichome fragments) that were not successfully removed during the filtering process. Once blockages were removed, counter readings returned to previous, unblocked values. Aberrant readings were omitted from sample estimates.

STATISTICAL ANalYSIS. Experimental design was replication over years with repeated sampling over hours within days within years for each crop or cultivar. Data were analyzed using PROC GLM (Type III SS) and PROC MEANS (SE) (SAS Institute, 1992). Percentages of pollen removed of the total pollen produced per flower were based on the number of pollen grains remaining per flower at each hour after anthesis in comparison to the total number of pollen grains produced by flowers collected prior to anthesis. The two assumptions of this technique were 1) total pollen production was similar between staminate flowers within each crop or cultivar and 2) all flowers in test plots were uniform with respect to probability of insect visitation. Regression equations (cucumber and muskmelon=logarithmic; watermelon=monomolecular growth function) for pollen removal rates are provided.

\section{Results}

The total percentages of pollen grains removed during anthesis were $61 \%$ (cucumber; Fig. 1), $44 \%$ to $62 \%$ (muskmelon; Fig. 2A), and $81 \%$ (watermelon; Fig. 3A) of the total pollen grains produced by staminate flowers. The considerable amount of pollen remaining

Fig. 1. Cucumber. Cumulative percentages (mean $\pm \mathrm{SE}$ ) of pollen depletion based on total pollen production (A) and as a percentage of total removed (B) from staminate flowers during anthesis. Data combined over years (1998 and 1999). For regression equations, $\mathrm{x}=$ hours after anthesis +1 .

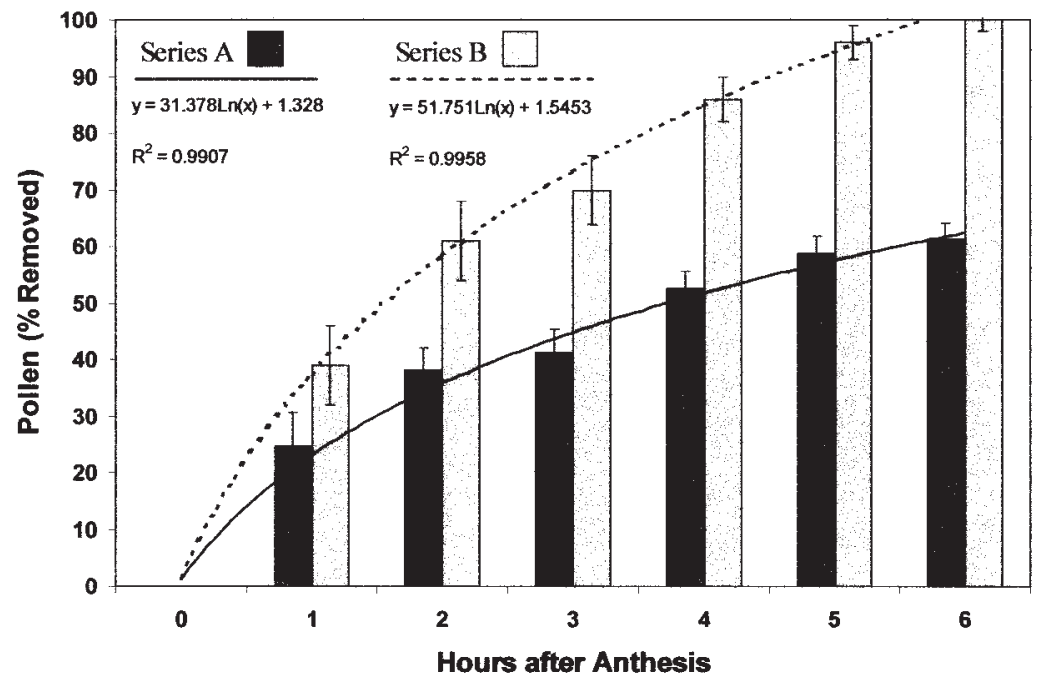



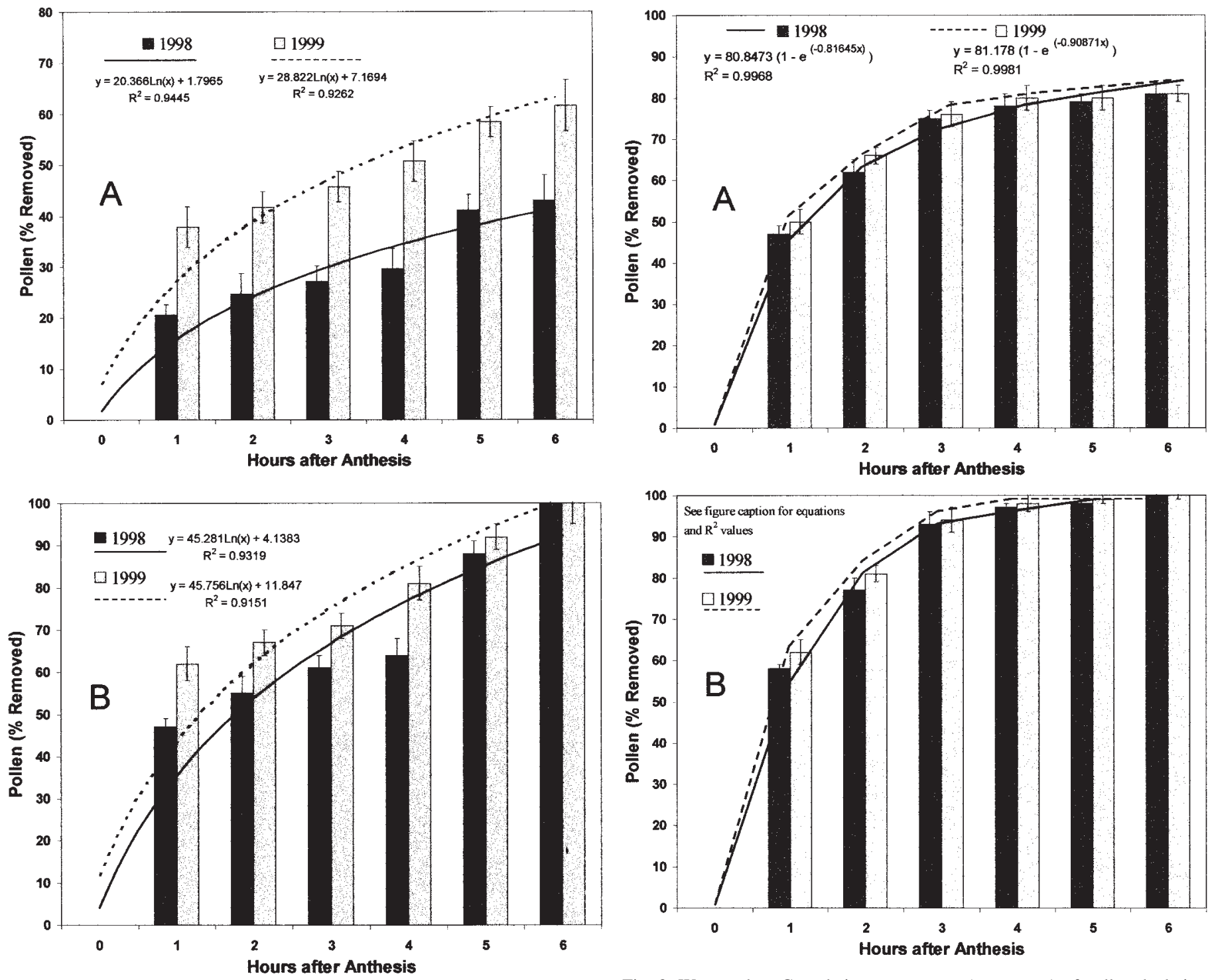

Fig. 2. Muskmelon. Cumulative percentages (mean $\pm \mathrm{SE}$ ) of pollen depletion based on total pollen production (A) and as a percentage of total removed (B) from staminate flowers during anthesis, 1998 and 1999. For regression equations, $x$ $=$ hours after anthesis +1 .

on anthers after anthesis aroused the additional question concerning the rate of depletion for the pollen that was actually removed. A second category of pollen depletion was therefore created to describe the cumulative amount of pollen removed as a percentage of the total amount of pollen removed during cucumber (Fig. 1), muskmelon (Fig. 2B), and watermelon (Fig. 3B) anthesis. The two categories of pollen depletion are thus based on two factors: the total amount of pollen initially produced by flowers and the total amount of pollen actually removed from flowers; these italicized words were included below to facilitate distinction between the two pollen depletion categories.

CUCUMBER. Staminate and pistillate flowers of both gynoecious cultivars, 'Calypso' (pickling) and 'Dasher II' (slicing), and the monoecious pollinizer, 'Sumter', opened (full corolla expansion) between 0655 to $0705 \mathrm{HR}\left(20.2\right.$ to $\left.21.3^{\circ} \mathrm{C}\right)$ and closed (initial petal contraction) between 1330 to $1345 \mathrm{HR}\left(31.7\right.$ to $\left.33.0^{\circ} \mathrm{C}\right)$ on observation days in both years (Table 1). Staminate to pistillate flower ratios in cucumber plots averaged 6.4:1.2 flowers/plant/day (Table 2).

The total number of pollen grains produced by staminate $\mathrm{cu}-$

Fig. 3. Watermelon. Cumulative percentages (mean $\pm \mathrm{SE}$ ) of pollen depletion based on total pollen production (A) and as a percentage of total removed (B) from staminate flowers during anthesis, 1998 and 1999 (data combined for 'Fiesta' and 'Tri-X 313' in both years). For A regression equations, $\mathrm{x}=$ hours after anthesis +1 . For $B$, the regression equation for 1998 data is $y=99.7395(1$ $\left.{ }^{(-0.8079 x)}\right)$, with $R^{2}=0.9969$; and the regression equation for 1999 data is $\mathrm{y}=$ 99.7496( $\left.1-^{(-0.9255 \mathrm{x})}\right)$, with $R^{2}=0.9979$. For Figure 3B regression equations, $\mathrm{x}=$ hours after anthesis.

cumber flowers did not differ by year $(F=0.16 ; \mathrm{df}=1 ; P=0.7194)$, although it was slightly higher than in $1998(10464 \pm 1035)$ than in 1999 (10613 \pm 1354$)$. The number of pollen grains remaining on anthers at hourly sampling intervals was also similar between years $(F=0.25 ; \mathrm{df}=6 ; P=0.9549)$ and replications within years $(F=0.71$; $\mathrm{df}=6 ; P=0.6414)$. Therefore, cucumber pollen depletion data were combined for 1998 and 1999 (Fig. 1).

At anthesis, staminate cucumber flowers contained on average $10539 \pm 1118$ pollen grains/flower (range $=9568$ to 14144 ); and the number of pollen grains remaining on anthers decreased over time of day $(F=68.98 ; \mathrm{df}=6 ; P<0.0001)$ (Fig. 1$)$. The cumulative percentages of pollen depletion based on the total amount of pollen initially produced were $25 \%, 38 \%, 41 \%, 53 \%, 59 \%$ and $61 \%$ for hours after anthesis 1 to 6 , respectively (Fig. 1A). The cumulative percentages of pollen depletion based on the total amount of pollen actually removed were $39 \%, 61 \%, 70 \%, 86 \%, 96 \%$, and $100 \%$ for 
Table 1. Floral anthesis periods and initiation of bee foraging activity.

\begin{tabular}{|c|c|c|}
\hline Crop [year(s)] & Time of day $(\mathrm{H})$ & Temp $\left({ }^{\circ} \mathrm{C}\right)$ \\
\hline \multicolumn{3}{|l|}{ Cucumber (1998 and 1999) } \\
\hline \multicolumn{3}{|l|}{ Floral anthesis } \\
\hline Flowers open & $0655-0705$ & $20.2-21.3$ \\
\hline Flowers close & $1330-1345$ & $31.7-33.0$ \\
\hline \multicolumn{3}{|c|}{ Initiation of bee foraging } \\
\hline Apis mellifera & 0720-0730 & $>22.0$ \\
\hline Bombus impatiens & 0655-0705 & $20.2-21.3$ \\
\hline \multicolumn{3}{|c|}{ Muskmelon (1998 and 1999) } \\
\hline \multicolumn{3}{|c|}{ Floral anthesis } \\
\hline Flowers open & 0655-0705 & $20.8-21.7$ \\
\hline Flowers close & $1325-1335$ & $32.0-32.2$ \\
\hline \multicolumn{3}{|c|}{ Initiation of bee foraging } \\
\hline Apis mellifera & $0715-0720$ & $>22.6$ \\
\hline Bombus impatiens & $0655-0705$ & $20.8-21.7$ \\
\hline \multicolumn{3}{|l|}{ Watermelon (1998) } \\
\hline \multicolumn{3}{|l|}{ Floral anthesis } \\
\hline Flowers open & $0705-0710$ & $21.9-22.5$ \\
\hline Flowers close & $1320-1340$ & $31.0-32.2$ \\
\hline \multicolumn{3}{|c|}{ Initiation of bee foraging } \\
\hline Apis mellifera & 0730-0740 & $>23.3$ \\
\hline Bombus impatiens & $0705-0710$ & $21.9-22.5$ \\
\hline \multicolumn{3}{|l|}{ Watermelon (1999) } \\
\hline \multicolumn{3}{|l|}{ Floral anthesis } \\
\hline Flowers open & $0645-0655$ & $23.4-24.1$ \\
\hline Flowers close & $1300-1315$ & $34.0-35.0$ \\
\hline \multicolumn{3}{|c|}{ Initiation of bee foraging } \\
\hline Apis mellifera & $0715-0725$ & $>25.0$ \\
\hline Bombus impatiens & $0645-0655$ & $23.4-24.1$ \\
\hline
\end{tabular}

hours after anthesis 1 to 6 , respectively (Fig. 1B). Logarithmic regression equations describing the rates of pollen depletion based on total pollen production (Fig. 1A) and amount of pollen actually removed (Fig. 1B) are provided (where $\mathrm{x}=$ hours after anthesis +1 ).

Muskmelon. Staminate and pistillate 'Athena' flowers opened between 0655 to $0705 \mathrm{HR}\left(20.8\right.$ to $\left.21.7^{\circ} \mathrm{C}\right)$ and closed between 1325 to $1335 \mathrm{HR}$ ( 32.0 to $32.2^{\circ} \mathrm{C}$ ) on observation days for both years (Table 1). Staminate to pistillate flower ratios were 5.3:0.4 flowers/ plant/day (Table 2).

Like cucumber, total pollen grain production by staminate muskmelon flowers was higher in 1999 (11914 \pm 442) than in $1998(10437 \pm 491)$, but this difference was not significant $(F=$ $1.95 ; \mathrm{df}=1 ; P=0.2558)$. Unlike cucumber, the number of pollen grains remaining on anthers at hourly sampling intervals differed between years $(F=5.72$; df $=6 ; P<0.0001)$.

Fewer pollen grains remained per flower at equal sampling times in 1999 than in 1998; i.e., there was a faster rate of pollen depletion in $1999(F=14.58 ; \mathrm{df}=1 ; P=0.0003)$ (Fig. 2A). The cumulative percentages of pollen depletion based on the total amount of pollen initially produced were $21 \%, 25 \%, 27 \%, 30 \%, 41 \%$, and $44 \%$; and $38 \%, 42 \%, 46 \%, 51 \%, 58 \%$, and $62 \%$ for hours after anthesis 1 to 6 in 1998 and 1999, respectively.

Likewise, the pollen depletion rates based on the amount of pollen that was actually removed differed by year $(F=33.54$; $\mathrm{df}=$ $1 ; P<0.0001$ ) (Fig. 2B). The cumulative percentages of pollen depletion based on the total amount of pollen actually removed were $47 \%, 57 \%, 62 \%, 68 \%, 92 \%$, and $100 \%$; and $61 \%, 69 \%, 74 \%, 82 \%$, $94 \%$ and $100 \%$ for hours after anthesis 1 to 6 in 1998 and 1999 , respectively (Fig. 2B). Logarithmic regression equations describing the rates of pollen depletion based on total pollen production (Fig. 2A) and total amount of pollen actually removed (Fig. 2B) are provided (where $\mathrm{x}=$ hours after anthesis +1 ).

WATERMELON. In 1998, both staminate and pistillate flowers of 'Fiesta' (diploid) and 'Tri-X 313' (triploid) opened between 0705 to $0710 \mathrm{HR}\left(21.9\right.$ to $\left.22.5^{\circ} \mathrm{C}\right)$ and closed between 1320 to $1340 \mathrm{HR}$ (31.0 to $32.2^{\circ} \mathrm{C}$ ) (Table 1 ). Daily temperatures were slightly higher during observation in 1999 (by 1.8 to $2.2^{\circ} \mathrm{C}$, on average); as a result, watermelon flowers opened ( 0645 to $0655 \mathrm{HR} ; 23.4$ to $24.1^{\circ} \mathrm{C}$ ) and closed ( 1300 to $1315 \mathrm{HR} ; 34.0$ to $\left.35.0^{\circ} \mathrm{C}\right) 20$ to 30 min earlier in 1999 than in 1998. The times of flower sample collection were therefore adjusted to keep sampling periods at hourly increments after anthesis. Staminate to pistillate ratios were similar between years and cultivars (Table 2).

Total pollen production by staminate watermelon flowers did not differ by cultivar $(F=0.51$; df $=1 ; P=0.5017)$ or years $(F=0.07$; df $=1 ; P=0.8049$ ), although pollen production was slightly higher in $1999(30853 \pm 535)$ than in 1998 (30624 \pm 615$)$. Overall, diploid and triploid flowers produced on average $30739 \pm 587$ pollen grain/ flower. Unlike muskmelon, the number of pollen grains remaining on anthers at hourly sampling intervals was similar between years $(F=1.25 ; \mathrm{df}=6 ; P=0.2891)$, cultivars $(F=0.55 ; \mathrm{df}=1 ; P=0.4604)$ and replicates within years $(F=0.92 ; \mathrm{df}=6 ; P=0.4859)$. However, there was significant year main effect $(F=12.92 ; \mathrm{df}=1 ; P=0.0006)$, as the watermelon pollen depletion rate in 1999 was consistently faster than in 1998. Watermelon data are therefore combined over cultivars and presented by year (Fig. 3).

The cumulative percentages of pollen depletion based on total amount of pollen initially produced were 47\%, 62\%, 75\%, 78\%, $79 \%$, and $81 \%$; and $50 \%, 66 \%, 76 \%, 80 \%, 80 \%$, and $81 \%$ for hours after anthesis 1 to 6 in 1998 and 1999, respectively (Fig. 3A). Likewise, pollen depletion based on the amount of pollen that was actually removed differed by year $(F=25.13$; df $=1 ; P<0.0001)$ (Fig. 3B). The cumulative percentages of pollen depletion based on the total amount of pollen actually removed were $58 \%, 77 \%, 93 \%$,

Table 2. Plant populations and floral production.

\begin{tabular}{|c|c|c|c|c|c|}
\hline \multirow[b]{2}{*}{ Crop } & \multirow{2}{*}{$\begin{array}{l}\text { Year(s) } \\
\text { (sampling } \\
\text { dates) }\end{array}$} & \multirow{2}{*}{$\begin{array}{l}\text { Plant } \\
\text { type }\end{array}$} & \multirow{2}{*}{$\begin{array}{c}\text { Approximate } \\
\text { no. } \\
\text { plants }\end{array}$} & \multicolumn{2}{|c|}{$\begin{array}{c}\text { Mean no. } \\
\text { flowers/plant/d }\end{array}$} \\
\hline & & & & Staminate & Pistillate \\
\hline & (18-28 June) & Gynoecious & 1700 & --- & 1.2 \\
\hline Muskmelon & $\begin{array}{l}1998 \text { and } 1999 \\
\text { (26 June-5 July) }\end{array}$ & Monoecious & 150 & 5.3 & 0.4 \\
\hline & 1999 & Diploid & 138 & 8.5 & 0.5 \\
\hline & (10-23 July) & Triploid & 276 & 9.2 & 0.6 \\
\hline
\end{tabular}


Table 3. Mean number of foraging bees over time of day.

\begin{tabular}{|c|c|c|c|c|}
\hline Crop & Year(s) & $\begin{array}{c}\text { Hours } \\
\text { after } \\
\text { anthesis }\end{array}$ & $\begin{array}{c}\text { Time of } \\
\text { day } \\
(\mathrm{HR})\end{array}$ & $\begin{array}{c}\text { Mean no. of } \\
\text { foraging } \\
\text { bees }\end{array}$ \\
\hline \multirow[t]{7}{*}{ Cucumber } & 1998-99 & Anthesis & 0700 & --- \\
\hline & & 1 & 0800 & 37.2 \\
\hline & & 2 & 0900 & 46.8 \\
\hline & & 3 & 1000 & 56.4 \\
\hline & & 4 & 1100 & 62.3 \\
\hline & & 5 & 1200 & 65.3 \\
\hline & & 6 & 1300 & 59.0 \\
\hline \multirow[t]{7}{*}{ Muskmelon } & 1998 & Anthesis & 0700 & --- \\
\hline & & 1 & 0800 & 42.5 \\
\hline & & 2 & 0900 & 50.1 \\
\hline & & 3 & 1000 & 55.8 \\
\hline & & 4 & 1100 & 59.6 \\
\hline & & 5 & 1200 & 62.7 \\
\hline & & 6 & 1300 & 56.7 \\
\hline \multirow[t]{7}{*}{ Muskmelon } & 1999 & Anthesis & 0700 & --- \\
\hline & & 1 & 0800 & 49.6 \\
\hline & & 2 & 0900 & 57.3 \\
\hline & & 3 & 1000 & 63.1 \\
\hline & & 4 & 1100 & 69.5 \\
\hline & & 5 & 1200 & 72.1 \\
\hline & & 6 & 1300 & 62.9 \\
\hline \multirow[t]{7}{*}{ Watermelon } & 1998 & Anthesis & 0710 & --- \\
\hline & & 1 & 0810 & 31.8 \\
\hline & & 2 & 0910 & 40.2 \\
\hline & & 3 & 1010 & 47.6 \\
\hline & & 4 & 1110 & 56.5 \\
\hline & & 5 & 1210 & 61.6 \\
\hline & & 6 & 1310 & 54.0 \\
\hline \multirow[t]{7}{*}{ Watermelon } & 1999 & Anthesis & 0650 & --- \\
\hline & & 1 & 0750 & 37.7 \\
\hline & & 2 & 0850 & 45.3 \\
\hline & & 3 & 0950 & 55.9 \\
\hline & & 4 & 1050 & 63.4 \\
\hline & & 5 & 1150 & 68.5 \\
\hline & & 6 & 1250 & 52.1 \\
\hline
\end{tabular}

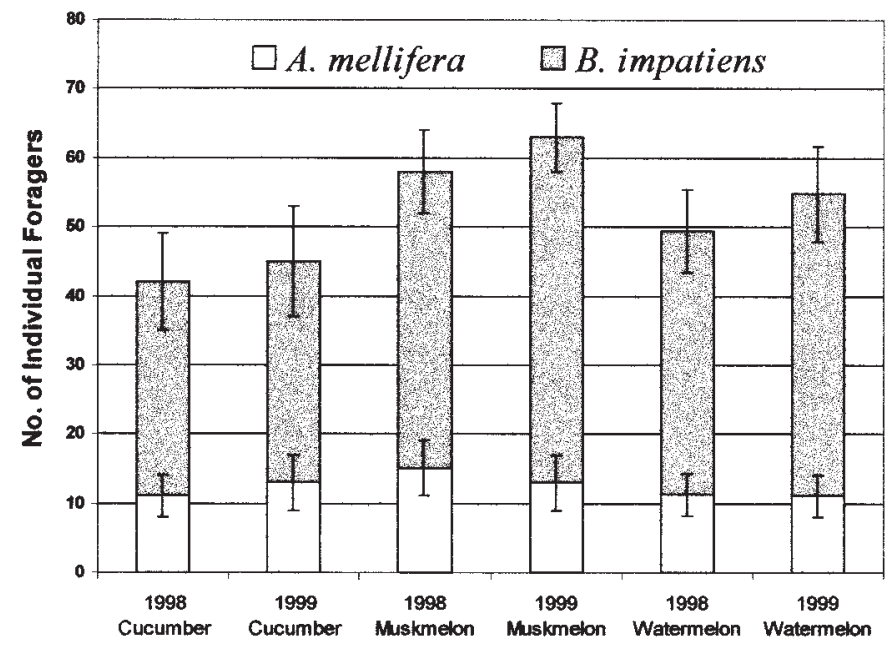

Fig. 4. Relative abundance and proportion of honey bees and bumble bees in cucumber, muskmelon, and watermelon plots, 1998 and 1999.
$97 \%, 98 \%$, and $100 \%$; and $62 \%, 81 \%, 94 \%, 98 \%, 99 \%$, and $100 \%$ for hours after anthesis 1 to 6 in 1998 and 1999, respectively. Regression equations (monomolecular growth function) describing the rates of pollen depletion based on total pollen production (Fig. 3A) and total amount of pollen actually removed (Fig. 3B) are provided (where $\mathrm{x}=$ hours after anthesis).

BEE FORAGING BEHAVIOR AND ABUNDANCE. For all crops in both years, bumble bees initiated foraging activity 15 to $40 \mathrm{~min}$ before honey bees (Table 1), and both species foraged until flowers closed (Table 3). The overall abundance of bees (total number of foragers of each species combined) increased over time of day on each crop $(P<0.0001$ for all crops), at least until flowers began to close around or shortly after $1300 \mathrm{HR}$. The total number of bees was similar between years on cucumber $(F=0.28$; df $=1 ; P=0.5981)$, but differed by year for both muskmelon $(F=15.89 ; \mathrm{df}=1 ; P<0.0001)$ and watermelon $(F=11.08$; $\mathrm{df}=1 ; P=0.0014)$ (Fig. 4$)$, which was attributed to an increase in the wild bumble bee population in 1999. Because the time-of-day effect was so large in all analyses, it was not possible to correlate the differences in pollen depletion rates between years with differences in bee abundance between years for muskmelon and watermelon.

\section{Discussion}

These studies demonstrate that 1) total pollen production does not necessarily reflect total pollen availability to floral visitors, at least for the crops and pollinators used here; 2) most pollen actually removed from flowers (the accessible pollen) occurred during the first $2 \mathrm{~h}$ after anthesis, which is when these crops are most receptive to pollination; 3 ) nonviable, triploid watermelon pollen is produced in similar amounts and removed as rapidly as viable, diploid watermelon pollen; and 4) variability in pollinator abundance may influence the rate of pollen depletion from flowers.

Staminate to pistillate flower ratios and the times and air temperatures at which flowers opened and closed (Tables 1 and 2) are similar to those reported by other researchers in other locations (Free, 1993). The total number of pollen grains produced by staminate cucumber, muskmelon, and watermelon flowers were similar between years and averaged 10539, 11176, and 30739 pollen grains/flower, respectively. It is interesting to note that total pollen production was higher for all crops in 1999 than in 1998, but these differences were not significant. This may have been coincidental or this trend might be related to differences between years with respect to soil type or overall environmental conditions that could have influenced pollen production through their effects on plant vigor.

In terms of the cumulative percentages of the total pollen that was actually removed, greater than $57 \%$ occurred during the first $2 \mathrm{~h}$ after anthesis for staminate cucumber (Fig. 1) and muskmelon (Fig. 2B) flowers, and greater than $77 \%$ occurred for both diploid and triploid watermelon flowers (Fig. 3B). Thus, the majority of pollen that was actually removed from flowers occurred within a relatively short time period after anthesis.

Perhaps most interesting was that the total amount of pollen removed was well below $100 \%$ of the total pollen produced. After $6 \mathrm{~h}$ of flowers being open and exposed to bee visitation, only $61 \%$ (cucumber; Fig. 1), $44 \%$ to $62 \%$ (muskmelon; Fig. 2A), and $81 \%$ (watermelon; Fig, 3A) of the total pollen produced had been removed from staminate flowers. This is in contrast to the visual estimations of pollen removal on andromonoecious muskmelon by Orr and Eisikowitch (1988) which reached $100 \%$ before flower closure. From personal experience, visual estimations such as these 

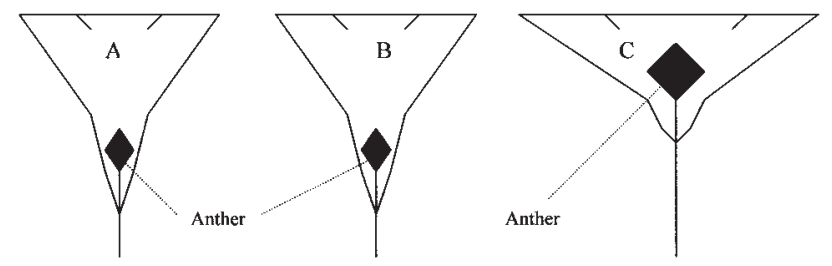

Fig. 5. Relative position of anthers in staminate cucumber (A), muskmelon (B), and watermelon $(\mathbf{C})$ flowers.

often underestimate the amount of pollen remaining on anthers due to the small size of pollen grains and the difficulty in detecting small and dispersed volumes of pollen. Our results were similar to those of Mann (1953) and Wolf et al. (1999) who reported 75\% to $85 \%$ and $65 \%$ to $100 \%$ pollen removal from andromonoecious muskmelon and diploid watermelon, respectively.

The amounts of pollen remaining on staminate cucumber, muskmelon, and watermelon flowers after anthesis suggest that a sizeable proportion of the total pollen produced may not be available to bees, which may be related to floral structure. This is supported by the fact that overall pollen removal was highest for watermelon, where the anthers are more exposed to bees and therefore possibly more accessible to bees, than are the anthers of cucumber and muskmelon (Fig. 5). Lower overall pollen depletion rates for cucumber (and possibly muskmelon) may have also stemmed from the fact that cucumber pollen has a generally low attractiveness to bees in comparison to the attractiveness of other blooming crops and weed species (Collison and Martin, 1979; Kauffeld and Williams, 1972). A third possible explanation could be that in their native ranges, cucumber and muskmelon plants may be visited and pollinated by bee species that are smaller in size than the European honey bees (Apis mellifera L.) or North American Bombus sp. used in our studies. Both cucumber and muskmelon are believed to have originated in central Asia (Robinson and Decker-Walters, 1997), where other bees such as the Asian honey bee (A. cerana F.) and dwarf honey bee (A. florea $\mathrm{F}$.) are prevalent, smaller in size than $A$. mellifera, and have been documented as floral visitors of these crops in Asiatic cucurbit fields (Free, 1993). A smaller body size may increase the efficiency with which pollen is removed from flowers with more constricted corolla bases. Watermelon originates from central Africa where races of $A$. mellifera are abundant. It would be interesting to compare cucurbit pollen depletion rates using the smaller Asiatic Apis species with the larger-sized A. mellifera used in Europe and the New World.

The differences in pollen depletion rates between years found for muskmelon and watermelon may be attributed to the elevated wild Bombus populations in 1999 vs. 1998 (Fig. 4). This is supported, at least in part, by the fact that pollen removal rates and bee abundance on cucumber were similar between years. Although the time-of-day effects were strong enough such that no correlation between differential pollen depletion rate and bee abundance between years was possible, it can be speculated that the presence of additional pollinators may have driven the faster pollen depletion rates in 1999 vs. 1998. This seems likely as overall floral production and pollen levels at anthesis were similar between years.

A companion study evaluating floral visitation and pollen deposition rates by honey bees and bumble bees also suggested that the elevated number of bees in 1999 may have influenced bee foraging dynamics (Stanghellini, 2000; Stanghellini et al., 2002). Both bee species visited more flowers/min (possibly through increased nectar depletion) and deposited fewer pollen grains per floral visit (possibly due to fewer pollen grains being available per bee) in 1999 than in 1998. The observed Bombus population differences in muskmelon and watermelon but not in cucumber may be a result of the latter sampling periods for muskmelon and watermelon (Table 2), as individual Bombus colony populations would still be increasing during that time interval and would peak in August to September under North Carolina conditions. Wild Bombus populations fluctuate naturally by year, season, and geographical location for a variety of reasons (Corbet, 1996).

The between-year variation in pollinator abundance and its influence on rates of pollen depletion (described here) and pollen deposition (Stanghellini, et al., 2002) suggest that variable bee densities likely affect fruit and seed setting patterns and overall crop yield response. Many studies document the positive effect of increased honey bee colony stocking rates (i.e., colonies/ha) on increased yields of bee-pollinated crops (Free, 1993). Similarly, differences in temporal pollinator density and/or pollinator diversity have been suggested in both crop and natural plant settings as primary factors influencing pollen removal and yield response (e.g., Cane et al., 1996; Fell, 1986; Goodell and Thomson, 1997; Willmer et al., 1994), seed and offspring quality (e.g., Spira et al., 1992; Waser and Price, 1991), insect-mediated pollen dispersal patterns (e.g., Harder, 1990; Harder and Wilson, 1998; Ordway et al., 1987, Young and Stanton, 1990), pollen-mediated gene flow (Kohn and Casper, 1992; Schmitt, 1980), and, ultimately, overall plant reproductive success (e.g., Thomson, 1982; Thomson et al., 1989).

Of special interest here is that triploid watermelon pollen was removed just as quickly and in similar amounts as diploid pollen $(P$ $=0.4604)$, which suggests that nonviable, triploid watermelon pollen might still be attractive to bees as a food resource. This contrasts to other studies that demonstrated that honey bees and bumble bees avoid sterile or abortive pollen on onion (Allium cepa L.) and certified seed potato (Solanum tuberosum L.) (Batra, 1993; Nye et al., 1971; Sanford and Hanneman, 1981). Regardless of whether triploid pollen is actively collected or simply discarded by bees, the pollen depletion rates suggest that a considerable amount of triploid pollen may be transferred to bees and therefore deposited onto stigmas. It is unknown if triploid pollen causes a rejection reaction as occurs with foreign (interspecific) pollen when placed on watermelon stigmas (Sedgley and Blesing, 1982), or if triploid pollen grains simply occupy stigmatic surface area. Either way, the loss of stigmatic papilla cells or obstruction to them likely increases the number of bee visits needed for individual fruit set in triploid watermelon production fields. Diploid flowers in solid diploid watermelon fields each require at least 6 to 8 honey bee visits to set fruit (Adlerz, 1966; Stanghellini et al., 1997). The number of bee visits required for fruit set under triploid watermelon field conditions, where nonviable pollen outnumbers viable pollen at least 2:1, has not yet been determined.

\section{Literature Cited}

Adlerz, W.C. 1966. Honey bee visit numbers and watermelon pollination. J. Econ. Entomol. 59:28-30.

Batra, S.W.T. 1993. Male-fertile potato flowers are selectively buzzpollinated only by Bombus terricola Kirby in upstate New York. J. Kan. Entomol. Soc. 66:252-254.

Berger, L.A., B.E. Vaissiere, J.O. Moffett, and S.J. Merritt. 1988. Bombus spp. (Hymenoptera: Apidae) as pollinators of male-sterile upland cotton on the Texas High Plains. Environ. Entomol. 17:769-794.

Bohart, G.E., W.P. Nye, and L.R. Hawthorn. 1970. Onion pollination as affected by different levels of pollinator activity. Utah Agr. Expt. Sta. Bul. 482.

Cane, J.H., D. Schiffhauer, and L.J. Kervin. 1996. Pollination, foraging, and nesting ecology of the leaf-cutting bee Megachile (Delomegachile) 
addenda (Hymenoptera: Megachilidae) on cranberry beds. Ann. Entomol. Soc. Amer. 89:361-367.

Collison, C.H. and E.C. Martin. 1979. Behavior of honey bee foraging on male and female flowers of Cucumis sativus. J. Apicult. Res. 18:184-190.

Connor, L.J. and E.C. Martin. 1970. The effect of delayed pollination on yields of cucumbers grown for machine harvest. J. Amer. Hort. Sci. 95:456-458.

Connor, L.J. and E.C. Martin. 1971. Staminate:pistillate flower ratio best suited for the production of gynoecious hybrid cucumbers for machine harvest. HortScience 6:337-339.

Corbet, S.A. 1996. Why bumble bees are special. In: A. Matheson (ed.). Bumble bees for pleasure and profit. Intl. Bee Res. Assn., Cardiff, U.K.

Fell, R.D. 1986. Foraging behaviors of Apis mellifera L. and Bombus spp. on oilseed sunflower (Helianthus annuus L.). J. Kan. Entomol. Soc. 59:72-91.

Free, J.B. 1993. Insect pollination of crops, 2nd ed. Academic Press, London.

Gary, N.E., P.C. Witherell, and J. Marston. 1972. Foraging range and distribution of honey bees and bumble bees visiting apple. Acta Hort. 437:103-107.

Goodell K., and J.D. Thomson. 1997. Comparisons of pollen removal and deposition by honey bees and bumble bees visiting apple. Acta Hort. 437:103-107.

Harder, L.D. 1990. Pollen removal by bumble bees and its implications for pollen dispersal. Ecology 71:1110-1125.

Harder, L.D., and W.G. Wilson. 1998. Theoretical consequences of heterogeneous transport conditions for pollen dispersal by animals. Ecology 79:2789-2807.

Kauffeld, N.M. and P.H. Williams. 1972. Honey bees as pollinators of pickling cucumbers in Wisconsin. Amer. Bee J. 112:252-254.

Kearns, C.A. and D.W. Inouye. 1993. Techniques for pollination biologists. Univ. Press of Colo., Niwot.

Knapp, S.J., L.A. Tagliani, and B.H. Lui. 1991. Outcrossing rates of experimental populations of Cuphea lanceolata. PlantBreeding 106:334 337.

Kohn, J.R. and B.B. Casper. 1992. Pollen-mediated gene flow in Cucurbita foetidissima (Cucurbitaceae). Amer. J. Bot. 79:57-62.

Levin, D.A. 1981. Dispersal vs. gene flow in plants. Ann. Mo. Bot. Gard. 68:370-378.

Mann, L.K. 1953. Honey bee activity in relation to pollination and fruit set in the cantaloupe (Cucumis melo). Amer. J. Bot. 40:545-553.

Motes, J.E. 1977. Pickling cucumbers: Production harvesting. Mich. State Univ. Ext. Bul. E-837.

Niles, G.A. and C.V. Feaster. 1984. Breeding, pp. 201-231. In: R.J. Kohel and C.F. Lewis (eds.). Cotton agronomy monograph. Crop Sci. Soc., Madison, Wis.

Nye, W.P., G.D. Waller, and N.D. Walters. 1971. Factors affecting pollination of onions in Idaho during 1969. J. Amer. Soc. Hort. Sci. 96:330-332.

Ordway, E., S.L. Buchmann, R.O. Kuehl, and C.W. Shipman. 1987. Pollen dispersal in Cucurbita foetidissima (Cucurbitaceae) by bees of the genera Apis, Peponapis, and Xenoglossa (Hymenoptera: Apidae, Anthophoridae). J. Kan. Entomol. Soc. 60:489-503.

Orr, N., and D. Eisikowitch. 1988. Interaction between melon (Cucumis melo) flowers and honey bees under extreme desert conditions in Israel. Apidologie 19:85-96.

Particle Data. 1987. Elzone 180 Instruction manual. Particle Data, Inc., Elmhurst, Ill.

Robinson, R.W., and D.S. Decker-Walters. 1997. Cucurbits. CAB Intl., New York.

Sanders, D.C., J.M. Davis, J.R. Schultheis, and D.W. Monks. 1999. Suggested commercial vegetable varieties. N.C. State Univ. Hort. Info. Lflt. 00.
Sanford, J.C. and R.E. Hanneman. 1981. The use of bees for the purpose of intermating potato. Amer. Potato J. 58:481-485.

SAS Institute. 1992. SAS/STAT user's guide, ver. 6, 4th ed. SAS Inst., Cary, N.C.

Schmitt, J. 1980. Pollinator foraging behavior and gene dispersal in Senecio (Compositae). Evolution 34:934-943.

Schultheis, J.R. 1995. Commercial watermelon production. N.C. Coop. Ext. Serv. Hort. Info. Lflt. 30.

Schultheis, J.R. 1998. Muskmelons (cantaloupes). N.C. State Univ. Hort. Info. Lflt. 8.

Schultheis, J.R, C.W. Averre, M.D. Boyette, E.A. Estes, G.J. Holmes, D.W. Monks, and K.A. Sorensen. 1998. Commercial production of pickling and slicing cucumbers in North Carolina. N.C. Coop. Ext. Serv. Bul. AG-552.

Sedgley, M. and M.A. Blesing. 1982. Foreign pollination for the stigma of watermelon [Citrullus lantus (Thunb.) Matsum. \& Nakai]. Bot. Gaz. 143:210-215.

Spira, T.P., A.A. Snow, D.F. Whigam, and J. Leak. 1992. Flower visitation, pollen deposition, and pollen-tube competition in Hibiscus moscheutos (Malvaceae). Amer. J. Bot. 79:428-433

Stanghellini, M.S. 2000. Honey bee (Apis mellifera L.) and bumble bee (Bombus impatiens Cresson) pollination efficacy on field-grown cucumber and watermelon. PhD diss., N.C. State Univ, Raleigh.

Stanghellini, M.S., J.T. Ambrose, and J.R. Schultheis. 1997. The effects of honey bee and bumble bee pollination on the fruit set and abortion of cucumber and watermelon. Amer. Bee J. 137:386-391.

Stanghellini, M.S., J.T. Ambrose, and J.R. Schultheis. 1998a. Seed production in watermelon: A comparison between two commercially available pollinators. HortScience 33:28-30.

Stanghellini, M.S., J.T. Ambrose, and J.R. Schultheis. 1998b. Using commercial bumble bee colonies as backup pollinators for honey bees to produce cucumbers and watermelons. HortTechnology 8:590-594.

Stanghellini, M.S., J.R. Schultheis, and J.T. Ambrose. 2002. Bee activity, floral visitation and pollen deposition comparisons between honey bees and bumble bees on field-grown cucumber and watermelon. J. Apicult. Res. (in press).

Strickler, K. 1979. Specialization and foraging efficiency of solitary bees. Ecology 60:998-1009.

Thomson, J.D. 1982. Patterns of visitation by animal pollinators. Oikos 39:241-250.

Thomson, J.D., M.A. McKenna, and M.B. Cruzan. 1989. Temporal patterns of nectar and pollen production in Aralia hispida: Implications for reproductive success. Ecology 70:1061-1068.

Vann Wann, E. 1993. Cucumber yield response to plant density and spatial arrangement. J. Prod. Agr. 6:253-255.

Waser, N.M. and M.V. Price. 1983. Optimal and actual outcrossing in plants, and the nature of plant-pollinator interaction, p. 341-359. In: C.E. Jones and R.J. Little (eds.). Handbook of experimental pollination biology. Van Nostrand Reinhold Co., New York.

Waser, N.M. and M.V. Price. 1991. Outcrossing distance effects in Delphinium nelsonii: Pollen loads, pollen tubes, and seed set. Ecology 72:171-179.

Williams, I.H., A.H. Marshall, and T.P.T. Michaelson-Yeates. 1997. Siring efficiency in white clover (Trifolium repens). Acta Hort. 437:147152.

Willmer, P.G., A.A.M. Bataw, and J.P. Hughes. The superiority of bumble bees to honey bees as pollinators: Insect visits to raspberry flowers. Ecol. Entomol. 19:271-284.

Wolf, S., Y. Lensky, and N. Paldi. 1999. Genetic variability in flower attractiveness to honey bees (Apis mellifera L.) within the genus Citrullus. HortScience 34:860-863.

Young, H.J., and M.L. Stanton. 1990. Influences of floral variation on pollen removal and seed production in wild radish. Ecology 71:536-547. 